\title{
Philippine-US relations: the relevance of an evolving alliance
}

\author{
Ava Patricia C. Avila ${ }^{*}$ (D) and Justin Goldman²
}

\author{
*Correspondence: \\ ava.avila@nie.edu.sg \\ ${ }^{1}$ National Institute \\ of Education, Singapore, \\ Singapore \\ Full list of author information \\ is available at the end of the \\ article
}

\begin{abstract}
The Philippines and the United States maintain close ties that are grounded in a Mutual Defense Treaty signed in 1951. Security cooperation has been a hallmark despite evolving dynamics in the bilateral relationship, including a US colonial legacy that continues to cast a long shadow for many Filipinos. While contentious politics and domestic limitations present a potential constraint on the upward trajectory of the alliance relationship, there are indications that this expanded engagement can continue beyond the Aquino administration. The paper examines the condition of Philippine forces under President Aquino, the International Peace and Security Plan to pursue a credible external defense capability, the process of security sector reform, and matters pursuing a strong Philippine-US alliance.
\end{abstract}

Keywords: Philippine-US alliance, Peace and security, Security sector reform, Maritime domain awareness, Capability development, Modernization

\section{Background}

The Philippines and the United States maintain close ties that are grounded in a Mutual Defense Treaty signed in 1951. Security cooperation has been a hallmark despite evolving dynamics in the bilateral relationship, including a US colonial legacy that continues to cast a long shadow for many Filipinos. Nearly a century of US military presence in the Philippines, which resulted from the Spanish-American War, ended when the Philippine Senate voted 12-11 in September 1991 to reject a treaty that would have kept Subic Bay Naval Station in place (Shenon 1992). Today, alliance relations with the US can be characterized by an increasingly active tempo of cooperation (De Castro 2007). While contentious politics and domestic limitations present a potential constraint on the upward trajectory of the alliance relationship, there are indications that this expanded engagement can continue beyond the Aquino administration.

The stage was set for a more active level of alliance engagement with two key signals prior to President Aquino entering office. First, the Chinese submitted a map with a nine-dashed line to the United Nations in May 2009 laying claim to the vast majority of the South China Sea. Second, the administration of US President Obama has committed considerable time and emphasis to Southeast Asia as well as to regional multilateral institutions as part of its "rebalance" policy to the Asia-Pacific region (Daggett et al. 2012). This paper begins by examining the condition of Philippine forces as President

(C) 2015 Avila and Goldman. This article is distributed under the terms of the Creative Commons Attribution 4.0 International License (http://creativecommons.org/licenses/by/4.0/), which permits unrestricted use, distribution, and reproduction in any medium, provided you give appropriate credit to the original author(s) and the source, provide a link to the Creative Commons license, and indicate if changes were made. 
Aquino entered office. The focus then turns to the International Peace and Security Plan (IPSP), which makes clear that in order to pursue a credible external defense capability, the Philippines has to mitigate the threat from internal armed groups, allowing for greater focus on territorial defense. Following that, the process of security sector reform is closely examined, particularly the professionalization of the Armed Forces of the Philippines (AFP). Finally, the piece will look forward, focusing on matters such as the Enhanced Defense Cooperation Agreement (EDCA) and combined efforts on modernization. These initiatives work towards enhancing a minimum credible defense capability in the Philippines.

\section{Methods}

Necessary fieldwork to substantiate the research was conducted in the Philippines. Interviews with persons from the government, academe and both Philippines and the US' military were carried out. This paper aims to add to the existing research on security with specifics on the Philippines and United States alliance, while at the same time providing a policy-oriented framework for its revolving existence amidst challenges.

\section{Results and discussion}

State of the AFP

While discussions over the end of US military bases focused on matters of social and economic development, as seen in the Bases Conversion and Development Act that took effect in March 1992, the AFP suffered as a result of the closure of these facilities. The military-to-military relationship declined as it was not until 1999 that the Philippine Senate ratified a Visiting Forces Agreement (VFA) that allowed for combined military operations between the two allied military forces. In the past, the Philippine Air Force knew it could count on spare parts and fuel necessary to sustain the readiness of aircraft and pilots (Avila 2014a, b). The level of reliance the AFP had on defense management support and the US military logistical system became clear upon closure of those bases. In conjunction with the end of the basing, the AFP was said to have lost an estimated US\$200 million in annual Foreign Military Financing (Carter 2011). With the reduced funding and a decrease in training opportunities, an ensuing decline in readiness occurred within the AFP. In the aftermath of September 11, 2001, the US was eager to pursue the global threat of terrorism, including cooperation with the Philippines. However, the US was not confident in the condition of the Philippine defense establishment from issues of organization to broader accountability, while the Philippines was reluctant to accept needed security assistance that included mandated reforms as well as being loathe to admit that their system of defense was in a degraded state (Comer 2010).

In order to more effectively combat the threat of terrorism while respecting the Philippine Constitution, the US would deploy forces in a strictly advise and assist role to build AFP capacity to more effectively engage the threat. President Arroyo and US President George W. Bush agreed in 2002 to a deployment of US personnel designated as Joint Special Operations Task Force-Philippines whose mission was to support a comprehensive approach by the AFP to combat terrorism (Lum and Dolven 2014). Under the context of the 2001 Authorization of the Use of Military Force following the September 11 attacks, funding was directed to support the training and equipping of a national 
counterterrorism capability, which became a requirement to field three Philippine Army Light Reaction Companies (Arthur 2012). The initial company was established with US Special Forces conducting the training, the second was trained up by a mix of US and Philippine Special Forces personnel, and the third was completely trained by the Philippine cadre, with a Light Reaction Battalion stood up in February 2004 that continued periodic training exchanges with their US counterparts (Maxwell 2013). Thus a very skilled and tactically proficient capability was stood up. However, their initial deployments were undertaken without the crucial command and control structure needed for them to integrate with other AFP units and concurrent operations (Maxwell 2004).

During a May 2003 visit to Washington DC, the US declared that it would designate the Philippines as a major non-NATO ally. President Bush announced that they "have agreed to launch a comprehensive review of Philippine security requirements, and how the United States can best support Philippine military modernization and reform" (Garamone 2003). During the reciprocal visit in Manila of October 2003, both Presidents committed to addressing the findings of the RP-US Joint Defense Assessment, which stated that the Philippines "has not been capable of neutralizing threats to Philippine stability, due, in large part, to systematic failures in policy planning and development, personnel management and leadership, budgeting and resource management, and acquisition" (Yabes 2008). While much of the focus was on the ground component engaging internal threats, the decline in the PAF was also apparent and in 2005 the AFP leadership decommissioned the remaining F-5 fighter aircraft, further reducing an already limited external defense capability (De Castro and Lohman 2012). The outcome of the JDA was the Philippine Defense Reform Program, which was designed to address these critical shortcomings. This multi-year effort would spend 2004-2005 focused on creating the reform structure and defining as well as standardizing processes, 2005-2008 (with key US funding as well as trainers) would concentrate on empowering the AFP through efforts including the "Battalions of Excellence" program, and 2008-2011 devoted to institutionalizing and sustaining the reform process (Chalk 2014).

\section{Campaign timeframe and the international peace and security plan}

During the 2010 presidential campaign, then-Senator Aquino emphasized issues of governance as he touted a "Mindanao Peace and Development Agenda" (Rood 2010). He highlighted the shortcomings in the approach taken by the Arroyo government with the Memorandum of Agreement on Ancestral Domain (MOA-AD) being declared unconstitutional by the Philippine Supreme Court in 2008 that led to extensive attacks from the Moro Islamic Liberation Front (MILF) across Mindanao and stressed the urgent need to renew talks (Integrated Regional Information Networks 2010). Recognizing that time was of the essence, efforts began upon his taking office to formulate a comprehensive national security policy, one that went well beyond kinetic effects to deal with internal threat groups. In his inaugural address, President Aquino emphasized "we shall defeat the enemy by wielding the tools of justice, social reform, and equitable governance leading to a better life" (Integrated Regional Information Networks 2010). Considerable effort and resources would need to be contributed towards reforming the AFP if such a vision was to be realized. 
The IPSP was mapped out over the six-year term in office the Aquino administration would serve. The first half (2011-2013) would focus on dealing with the internal security challenges posed by long-running insurgent groups, including the MILF as well as the communist New People's Army. In addition, it targeted terrorist groups including the Abu Sayyaf Group and Jemaah Islamiyah. As intended, this would allow the final 3 years for the AFP to return to a focus on territorial-defense, but the security environment around the archipelago would demand more urgent attention well before 2014 (De Castro and Lohman 2012). While progress had been made on the Philippine Defense Reform Program, the Aquino administration entered office with growing concerns such as the Bangsamoro Islamic Freedom Fighters, a violent faction that broke from the MILF. Shortly after the IPSP was rolled out on the January 1, 2011, the MILF agreed to a new round of peace talks. These talks, held in Kuala Lumpur, marked a key step forward after talks collapsed 30 months beforehand with the breakdown of MOA-AD (McGeown 2011). Just weeks later a survey ship commissioned by the Philippine Department of Energy was conducting oil exploration surveys in Reed Bank, just 80 nautical miles west of the Philippine island of Palawan when two Chinese patrol boats confronted it and threatened to ram it, forcing it to withdrawal (The Economist 2011). It was clear that critical action was needed on both internal and external challenges to reach what has proven to be an elusive peace.

The IPSP placed an increased emphasis on human security, where efforts would go beyond the security of the state to focus on the wellbeing of citizens within their communities. President Aquino's IPSP message acknowledged that a purely military solution will not end the persistent conflicts in the country; the plan supports the primacy of the peace process (Armed Forces of the Philippines 2011). Key leaders acknowledged that concepts such as human security laid out in the IPSP were a new way of operating for the AFP and it took sustained efforts to communicate these priorities down to lower tactical levels for this counterinsurgency approach to be viable. Such an effort dominated the focus of the Army-centric senior leadership in the AFP, but the territorial concerns continued to grow. In early May 2011 at the ASEAN Summit, President Aquino sought to rally support of fellow claimants to the South China Sea towards a unified position in opposition to China, but ensuring ASEAN unity on the matter remained a challenge. Shortly after that meeting, the Philippines announced the acquisition of BRP Gregorio del Pilar (PF-15), the former US Coast Guard Hamilton [High Endurance Cutter (WHEC)-715] was transferred to the Philippine Navy on May 13, 2011 under the Excess Defense Articles program, which allows such a transfer to support the modernization efforts of US allies (Tonson 2011). Upon entering service it became the Philippine Navy's largest warship, adding sorely needed capability.

It was clear that pursuing a secure environment would be a long-term proposition. The US sought to reassure the Philippines on its commitment to its ally with key pronouncements from senior leaders. In July 2011, the US Senate weighed in on the issue condemning the Chinese use of force in disputed South China Sea (Ryan 2011). US Secretary of State Hillary Clinton travelled to Manila in November 2011 and with Philippines Foreign Secretary Albert Del Rosario signed the Manila Declaration, reaffirming the Mutual Defense Treaty as they commemorated those ties on their 60th Anniversary (US Department of State 2011). However, the Del Pillar and the alliance relationship were tested in 
short order. Del Pillar was sent to respond to Chinese fishing vessels that surveillance aircraft spotted in Scarborough Shoal, some 120 miles west of Subic Bay. The Chinese accused Manila of militarizing the dispute by using a naval vessel and dispatched their nearby maritime vessels that prevented the Philippines from arresting the fisherman in question, leading to heightened tensions (Perlez 2012). As the standoff continued, the US sought to broker a solution; with dozens of government and fishing vessels in the vicinity as typhoon season loomed, the US believed the Chinese had accepted terms for a mutual withdrawal (Dyer 2014). However, after the Philippine ships left Scarborough Shoal, the Chinese vessels remained, thereby changing the status quo in what some refer to as the "Scarborough Model" of gradually exerting greater control of disputed features (Ratner 2013). While the Philippines sought to rally support for its position on Scarborough and during the July 2010 ASEAN Ministers Meeting wanted a reference to the issue in the communique issued upon the conclusion of the meeting. However, with reportedly strong pressure from Beijing, no reference was included and for the first time in 45 years ASEAN's Foreign Ministers failed to release a communique (Emerson 2012). It is worth noting that in 2015 Cambodian Prime Minister Hun Sen publicly endorsed the Chinese position that territorial disputes in the South China Sea cannot be solved by ASEAN, making the description of such pressure in 2012 a very probable course of action (Sothanarith 2015).

The Aquino administration continued to deal with the territorial issues while peace talks pushed ahead with the MILF. In October 2012, a Framework Agreement on the Bangsamoro was signed with the MILF that laid out a settlement that would lead down a path to an autonomous political entity (Fernandez 2012). Research from Ateneo De Manila University found a $56 \%$ decline in the incidents of armed violence from the MILF in the first year of the IPSP, seen by the AFP as validating the approach that places the primacy on the peace process (Lapena 2012). However, any euphoric feeling from the breakthrough did not last in Mindanao. While traditionally the southern Philippines has not suffered the brunt of natural disasters when compared to other areas of the country, Typhoon Bopha ravaged communities such as Compostela Valley in December 2012, an unforgiving reminder of an ongoing requirement for the AFP to provide humanitarian assistance and disaster relief. At the time General Emmanuel Bautista was Chief of Army and while speaking to soldiers from the 10th Infantry Division, he spoke of working cooperatively in support of one's neighbors to effectively respond to natural calamities just as he emphasized such an attitude in mitigating problems that fuel internal conflict in the country. President Aquino further expressed his support for the approach by nominating General Bautista to become the AFP Chief of Staff in 2013, as he is credited with formulating the IPSP and thus an ideal choice to lead its further implementation (Dizon and Ubac 2013). AFP spirits were further boosted with the signing of Republic Act 10349, better known as the AFP Modernization Act, updating a 1995 law and extending it for another 15 years; this would infuse needed funding for the AFP's Capability Upgrade Program, supporting the transition to an external defense orientation (The Philippine Star 2012).

Bayanihan is a Filipino trait which means helping out one's neighbour to lessen their workload. This act of "community spirit" denotes working together to achieve a common and noble purpose. Popular images of bayanihan depict village members carrying the 
house of another community member to help them move to another location. As Aquiling-Dalisay (2004) notes, bayanihan is helping somebody regardless of social rank, leadership roles, and authority relationships. It is many hands and minds working together, each one contributing to the attainment of a shared goal (Leoncini 2005). All things considered, bayanihan is community orientation, community thinking, and community action (Andres et al. 1986).

For this reason, IPSP is also called Oplan Bayanihan. With its focus on human security, Oplan Bayanihan emphasizes the security of citizens within their communities, not just the security of the state. The plan was the result of widespread consultations with academia, civil society groups, and civilian government agencies. Oplan Bayanihan acknowledges that a purely military solution will not end the persistent conflicts in the country and it supports the primacy of the peace process. The government has sought to make the IPSP available to all stakeholders in order to have a shared understanding of its plans down to the barangay or village level. A major characteristic of the new IPSP is the importance it gives to civil-military relations (Avila 2011). Aside from addressing the needs of communities, civil-military relations also support the delivery of basic services by the local government units. For example, the implementation of IPSP Bayanihan in Negros Occidental province has been successful due to the collaboration between the civilian officials, the AFP, and non-governmental organizations. The province, known to be one of the hotbeds of communist insurgency in the Philippines, was able to establish a peace integration and development plan designed to undertake plans, programs, and activities to help address issues facing the marginalized communities in the province (Avila 2014a, b). This includes former rebels, threatened witnesses, para-military unit members, AFP personnel, and displaced civilians in the hinterlands. ${ }^{1}$ In the same vain, delivery of basic social services to hard-to-reach areas within some Philippine municipalities has been facilitated by assistance from the Philippine Army, which provides sorely needed security and logistical support. $^{2}$ The new IPSP is predicated on a "Whole-of-Nation" approach as national government officials in Manila have now realized that the local government units are the most critical actors in mitigating the conflict in order to realize peace and security.

Successive governments have made promises to mitigate conflicts, resume peace talks, and review the structure of the negotiation process. There have been multiple efforts along the lines of combined military operations and development projects, but these efforts were not sustainably implemented and none of them have succeeded in bringing about that elusive peace. The Aquino administration has repeatedly professed its commitment to human rights and as it pursues a political settlement with the MILF, the national government has had to implement dramatic changes within the AFP's approach to counterinsurgency and counterterrorism. This requires widespread and full support from the AFP, law enforcement, local government units, non-governmental organizations, the church, academe and Filipinos in their local communities. This is an ongoing pursuit, but operating in this manner has created vital space for negotiators from both sides to pursue a political settlement.

\footnotetext{
${ }^{1}$ Interview with BG Jon Aying, 303rd Infantry Brigade Commander, Philippine Army on 24 February 2014.

2 Interview with 2Lt Prolen Bonacua, 19th Infantry Brigade, Philippine Army on 22 September 2014. Interview with the Provincial Social Welfare and Development Office (Negros Occidental) on 24 February 2014. Interview with BG Jon Aying, 303rd Infantry Brigade Commander, Philippine Army on 24 February 2014.
} 


\section{Security sector reform}

Around the world, the importance of security sector reform (SSR) has been increasingly recognized, especially in promoting democratic principles to attain peace and sustainable development. Since SSR is a long-term pursuit, it must be pursued with strong determination and commitment by all its stakeholders. Reforming the security sector has been at the forefront of the Aquino administration's approach to defense policy as directed in the AFP's IPSP, making a clear case in support of this need (Armed Forces of the Philippines 2011). First, SSR is essential in a country that is trying to improve the quality of its democratic system of government that encompasses the executive, legislature and judicial branches. Second, according to the Human Development Network (2005) Report on the Philippines, SSR plays an important role in conflict prevention and peace-building, thus, having a professional security force is a necessary component to broader progress. Last, if implemented well, SSR can contribute to building the Philippines' capacity for exercising "good democratic governance" (Institute for Strategic and Development Studies 2011).

\section{Capability development and professionalism}

Even before the Spanish-American War of 1898, the concept of civilian authority over the military had already been practiced in the Philippines. Both the Malolos Constitution of 1899 and the 1935 Constitution clearly stipulated civilian oversight mechanisms to ensure that this concept was upheld (Agoncillo 1997). At that time, the Philippines was already considered as one of the models of democratic control of the armed forces in the developing world. Thus, it can be said that early Filipino political thinkers and leaders comprehended the significance of civilian control of the armed forces.

The Huk insurgency in the 1940s-1950s brought the military into the realm of the civilian sector. The counterinsurgency strategy employed against the Huk insurgents included non-traditional activities as soldiers were involved in delivering education, health, legal, and other technical services to communities with a large presence of Huk members and sympathizers (Hernandez 1979). Despite the seemingly obvious participation in civic action programs by the AFP beyond its traditional role, the constitutional basis for democratic civilian oversight was generally observed in practice (Goldberg 1976). Likewise, the US, through the International Military Education and Training program, helped lay the foundation for a democratic armed force during this time (Goldberg 1976).

The dynamic changed, however, when Ferdinand Marcos came into power. Upon the declaration of Martial Law in September 1972, he "invited" the AFP to be his partner in "governance." The military's involvement in economic, political and social affairs undermined the functional distinctions between the military and civilian officials. Through material gifts and other inducements of the AFP senior leadership, Marcos was able to secure military support and hold on to power for more than a decade. Additionally, Marcos extended the tenure of high-ranking officers loyal to him, thus, obstructing the promotion ladder for professional advancement (The Davide Fact-Finding Commission 1990). Even that was not enough. Marcos also set up military financial institutions that were exempted from banking regulations, which contributed heavily to military corruption (Ferrer and Hernandez 2013). 
The AFP's growing role in national development contributed to its politicization (Miranda 1992). As young officers graduate from the Philippine Military Academy with an idealistic mindset, they begin to see the realities on the ground as they are assigned to far-flung areas, leading ill-equipped and poorly paid troops, with basic social services usually provided by non-governmental organizations rather than the state. This created resentment towards high-ranking AFP officers, who enjoyed the largesse of Marcos while at the same time they were engaged in corrupt practices such as "cost of money" and "conversion."

Scholars have argued that the decline in military professionalism, politicization among the officers, growth in graft and corruption, and diminishing civilian control over the military were the results of shifts in policies that were aggravated by Martial Law and authoritarianism (Ferrer and Hernandez 2013). Accordingly, the military institution consisted of a fractured officer corps with highly politicized junior officers, where civilian oversight was totally ignored. As a consequence, the rebuilding of civilian authority through institutions ran into major challenges in the post-Marcos era (Ferrer and Hernandez 2013). Almost three decades since the 1986 People Power revolution and the eventual restoration of democracy, security sector governance is a goal that remains a work in progress. Some of these challenges include the ongoing role of the AFP in regime survival and in political succession, the continuing use of coercion principally through the AFP in dealing with domestic conflicts, and in the lack of effective civilian oversight (Alagappa 2001). Even after retirement, AFP officers remain active and engaged in the Department of National Defense (DND). Of the 12 DND Secretaries since 1986, more than half-eight to be exact-were former military officers (Department of National Defense 2015). This disregards one of the recommendations of the Davide and Feliciano Commissions tasked to investigate the failed December 1989 coup and the July 2003 Oakwood mutiny that appointment for Secretary of National Defense should come from a "civilian with capability, integrity and leadership (The Davide FactFinding Commission 1990; The Feliciano Fact-Finding Commission 2003)." The Feliciano Commission explains "civilian" as excluding retired military officers because no amount of time is enough to "de-militarize" the mindset of former AFP members. While retired military officers obtain civilian status, more likely than not, they are going to "bring the rigidity of hierarchy, seniority, camaraderie, and other aspects of the military culture in the government office that would obstruct reform" (The Feliciano Fact-Finding Commission 2003).

Another key characteristic for a mature relationship between the military and civilian officials is to shift internal security away from the AFP to concentrate on external defense (Ferrer and Hernandez 2013). The need for capacity building within the AFP for territorial defense was recognized by the Aquino Administration, which pushed for modernization to achieve a more credible defense, in the wake of Chinese assertiveness in the South China Sea. In 2013, the DND received one of the highest increases in its budget due to the pressing nature of this threat. According to one security scholar, by threatening the Philippines, China has given the Philippines an opportunity to

\footnotetext{
${ }^{3}$ Cost of money refers to money or resources from a military project that is lost to corrupt practices due to bribes. Conversion is the process of converting budgeted items into cash equivalent in order to procure non-budgeted items needed by soldiers on the ground, worse, diverted to pay something for personal gain.
} 
strengthen national unity. ${ }^{4}$ Such an endeavor is aligned with the US strategic interest in freedom of navigation along critical sea lanes such as the South China Sea. Hence, closer military ties between the two allies are crucial. The devastation of Typhoon Haiyan in November 2013 highlighted critical capability shortcomings in airlift and sealift within the AFP that limited their ability to respond rapidly to the humanitarian crisis (Jacobs 2013). The slight response from fellow ASEAN countries was noticeable as this disaster resulted in a limited collective effort despite the ASEAN Agreement on Disaster Management and Emergency Response whose mechanism was established in 2005 (Koh 2013). The US military commitment peaked with 66 military aircraft and 12 naval vessels on-station contributing to relief efforts with nearly 1000 US military personnel deployed providing rapid response to disaster stricken areas (Lum and Margesson 2014). The presence of US forces in the region that enabled the scale of the response underscored the broader US commitment to the Philippines.

Exercise Balikatan (literally shoulder-to-shoulder in Tagalog) is one of the higher profile training engagements with US forces conducted in the Philippines, especially in the post-9/11 security environment. This is a joint and combined training exercise hosted by the Philippines involving military personnel across the services from both the US and the AFP. In addition to improving interoperability among respective military units and drilling their service members, Balikatan also enhances positive military relations between the two countries. The benefits for the Philippines through these exercises have a direct impact not only in developing the expertise of the AFP, but also in fulfilling their responsibility for both external and internal defense. First, they enable the AFP to bridge the military technological gap between the two forces as it lacks not only the modern equipment, but also the training to employ this equipment (Agustin 2002). These exercises enhance the skills and capability of AFP members, which can enable skilled operators to act as force multipliers, adding tremendous value to their units. One such area is with the Philippine Marines based on Palawan operating jointly with the Philippine Navy to provide a coastal defense role as needed for territorial defense. While the AFP awaits the delivery of the two Strategic Sealift Vessels from Indonesian shipbuilder PT PAL, with planned delivery on track for May 2016 and May 2017, respectively, embarking with US Marines onboard US Navy ships is one of the only current opportunities they have to train in amphibious maneuver (Rahmat 2015). Second, the joint nature of these activities between allies provides a confidence-building atmosphere and facilitates the cross-flow of information. Third, the Balikatan Exercises sustain defense and security relations in the region by inviting additional partners to observe and take part.

Following the visit of President Obama to the Philippines in 2014, immediately after the EDCA was signed, a combined force of 5500 military personnel participated in the annual iteration of Balikatan. An AFP force of 3000 welcomed 2500 counterparts from the US for the exercise (Panda 2014). In an interview, former AFP Chief of Staff Emmanuel Bautista explained that Balikatan 2014 was focused on addressing "non-traditional threats" (Lopez 2014). The primary aim of the exercise was to increase the disaster response capability of the Philippines, which contends with an average of 20 typhoons a

${ }^{4}$ Interview with Rommel Banlaoi, Executive Director of the Philippine Institute on Peace, Violence and Terrorism Research on 13 November 2012. 
year (Milman 2015). Although not explicitly stated by either alliance member, a secondary goal was to increase readiness for the defense of Philippine territory.

In 2015, the Philippines hosted the largest amphibious exercise conducted since 2000, which brought together a force of over 11,000 American and Filipino troops. With the emphasis on amphibious operations, a US Marine contingent of 3500 from units based in the US as well as others forward-deployed to Japan joined the 5000 AFP participants in Exercise Balikatan. This was the largest iteration of the Balikatan in the post-9/11 era and comes at a time when both alliance partners are looking to expand an already active military-to-military relationship. With Marine Forces Pacific serving as the US Pacific Command's Executive Agent for Exercise Balikatan, it serves as the lead for consultative efforts with the AFP for AFP capability development. As the Philippines pursues military modernization, understood as a long-term undertaking, a critical role over the next two decades will be for the US to prevent the Chinese from achieving coercive gains while regional countries close the gap in terms of economic and military power, creating the dynamics where a future regional equilibrium could be realized (Rosen 2015).

In concurrence with the American re-balance to Asia policy, the US has been expanding its presence in the region over the last several years. Washington and Manila are involved in talks that would send US Marines to the Philippines on short-term rotational deployments. The move is politically sensitive because many Filipinos still strongly support the 1991 decision to end American's permanent presence. Additionally, with the misconduct cases involving US Marines, convincing the public about the significance of the deployment has become more challenging, although many regard the US presence as beneficial in the face of China's rapid and aggressive expansion in the South China Sea. An August 2015 report from the US Department of Defense assessed that since Chinese land reclamation efforts in the South China Sea began in December 2013, over 2900 acres of land had been reclaimed by June 2015 (Lubold 2015). These artificial islands could facilitate greater Chinese power projection into the Spratly Islands, at a time where they are increasing their presence in the vicinity, including building upon Mischief Reef that lies well within 200 nautical miles of Palawan.

\section{Political-military objective: developing a minimum credible defense}

As 2013 began with a General Election scheduled for May as the Aquino Administration was reaching the mid-point of its term in office, the approach to security policy was seen as on the right track. General Bautista took command of the AFP absolutely committed to the IPSP approach to building peace in Mindanao, but in his remarks upon assuming his new post, he crucially spoke of the "need to upgrade our joint and combined operations capabilities to be able to contain any external threats" (Bautista 2013). In January the Philippines, in accordance with the dispute settlement provisions of UN Convention on the Law of the Sea, initiated an arbitration case against China by issuing a Notification and Statement of Claim (Batongbacal 2015). The submission challenges the Chinese nine-dash line as interfering with Philippine sovereignty within its 200-mile exclusive economic zone which the Chinese unsurprisingly rejected. Secretary Del Rosario would later describe how an inability to make progress bilaterally on the issue forced the Philippines to seek third-party arbitration through the International Tribunal on the Law of the Sea (ITLOS) (Bauzon and Gutierrez 2015). While US policy remained to take no 
position on the legal merits of the competing claims to sovereignty in the South China Sea, US Navy Captain Stuart Bell, Deputy Assistant Judge Advocate General for International and Operations Law expressed that "one of the bright spots in international law jurisprudence is the ongoing arbitration between the Philippines and China (Goldman 2014)." With the issue brought clearly to the forefront, now it was incumbent upon the treaty allies to continue the push towards the defense posture objective.

\section{Maritime domain awareness and threats to the peace process}

The twin priorities of securing a lasting peace in Mindanao and developing the capability to ensure territorial defense of the country crossed over during two major crises originating from the Western part of the second-largest island in the Philippines. For the US, in order to truly deepen security cooperation focused on enhancing external defense, moving forward on the peace process with the MILF is essential. Both the MILF leadership and the Aquino administration saw utility in the role of Malaysia as a facilitator of the peace talks and in leading the International Monitoring Team tasked with ensuring the ceasefire between the two negotiating parties is observed (Franco 2013). On February 11, 2013, the standoff at Lahad Datu in Sabah erupted when a force of around 1000 calling themselves the "Royal Security Forces of the Sultanate of Sulu and North Borneo," went via speed boat from Tawi-Tawi to assert the unresolved territorial claim to Eastern Sabah (De La Cruz 2013). With both the Philippines and Malaysia facing General Elections and key negotiations remaining to reach a Comprehensive Agreement on the Bangsamoro, this crisis loomed large. Malaysian Prime Minister Najib Razak had to respond resolutely before facing Malaysian voters, while President Aquino needed to ensure continued Malaysian support for the peace talks knowing he could be vulnerable to criticism as the welfare of Filipinos hung in the balance. Malaysian security forces surrounded the armed insurgents, who held out for weeks as the two governments sought to negotiate an end to hostilities, with ultimately Malaysian forces moving into re-take Lahad Datu following air strikes from F/A-18 aircraft, with Operation Daulat concluding on 24 March 2013 (BBC News 2013).

In addition to the lack of maritime capacity in an area where Sulu, Palawan, Western Mindanao and North Borneo enclose the Sulu Sea, the Lahad Datu incident showed that not all of the Muslim population in Mindanao was in support of the current direction of national policy with respect to peace negotiations with the MILF. Moro National Liberation Front (MNLF) Chairman Nur Misuari declared Mindanao's independence in midAugust 2013, stating that the signing of the Framework Agreement was an abrogation of the 1996 peace agreement that the MNLF had signed with the Philippine Government (GMA News 2013). Early in the morning of 9 September, a MNLF force of approximately 100 fighters came ashore via small boats engaged an outnumbered Philippine Navy patrol in a firefight, entered the city, and took some 200 hostages captive (Bacani et al. 2013). The AFP reinforced its engaged personnel in Zamboanga rapidly shifting the balance in what became a deployment of overwhelming force, including the setting of a naval blockade. Efforts to negotiate a ceasefire within the first week of the standoff proved unsuccessful and the AFP began to re-take areas from the MNLF. Ultimately, the nearly the three-week crisis was brought to a conclusion as the final hostages were 
recovered and efforts could then shift towards recovery with over 100,000 residents of Zamboanga displaced by the fighting (Batino 2013).

The lack of maritime domain awareness created the conditions where the two crises were able to develop and threatened the broader objective of the peace process in Mindanao. For the US, an area that had received significant attention and resources, the Philippines Coast Watch South program, an effort that geographically emphasised Zamboanga and the Sulu Archipelago, did not deliver critical domain awareness needed at these times of consequence. Through "1206" funding, the US provided nearly $\$ 30$ million in 2007 and 2008 towards Coast Watch South, an interagency effort that was designed to provide sustained maritime surveillance with patrols at sea and in the air, focused on routes utilized by terrorist groups in moving in and out of the country (Laude 2008). In fact, the very Naval Special Operations Unit Six that first engaged the MNLF as they moved ashore is a unit that had worked with US Special Operations Forces, utilizing 1206 funding designated for "maritime train and equip for interdiction purposes," which reflected the emphasis put upon this role (Munson 2013). President Aquino has been a major proponent of this effort, signing Executive Order 57 in September 2011 to establish a National Coast Watch System, harmonizing diverse policies and programs that cut across multiple agencies including the Philippine Navy, the Philippine Coast Guard and the Philippine National Police-Maritime Group (Porcalla 2011). It is a shared pursuit of enhancing maritime governance that could begin to address the requirement for surveillance for the Philippines extensive maritime territory.

Several weeks prior to the Zamboanga crisis, the US Defense Threat Reduction Agency awarded Raytheon Company a contract to design and construct a National Coast Watch Center that would serve as the command post (Marasigan 2013). While building upon past engagements such as the May 2013 Table Top Exercise on Operational Planning, the contract awarded to Raytheon Company by DTRA in July 2013 includes the design and construction of the NCWC which commenced in April 2014 and was officially opened at PCG Headquarters in Manila 1 year later (Lee-Brago 2015). This multiyear effort is part of a maritime security project under DTRA's Weapons of Mass Destruction Proliferation Prevention Program which included numerous training engagements, including the May 2014 Operational Planning Workshop with Philippine officials. Plans are in place for future incremental improvements so when the project is fully realized, it will link more over a dozen stations and sensors, along with PCG vessels, to provide more enhanced maritime domain awareness in Philippine archipelagic waters and beyond. As per Executive Order 57, the NCWS is tasked to "gather, consolidate, synthesize, and disseminate information relevant to maritime security (Office of the President 2011)."

\section{Alliance management and the way ahead}

As the year 2015 unfolds, there is a clear rationale that the strengthening of RP-US relations that has been prioritized under the Aquino administration should endure in the next administration. In July 2015 the AFP's Deputy Director for Plans made clear the urgency with which the AFP and the DND saw having a long-term assessment of the strategic environment covering the development of capabilities and associated challenges, prepared and ready for the next President when their term begins in 2016. ${ }^{5}$ The 
events of April 28, 2015 reinforced the importance of sustaining this enhanced cooperation. It marked a year since the EDCA between the US and the Philippines was signed to reinvigorate security cooperation by giving US forces access to certain Philippine facilities on a rotational basis with the objective of alliance support to address AFP capability gaps (Gazmin and Goldberg 2014). While the EDCA is being challenged in the Supreme Court and related hearings have focused on how the US would respond to hypothetical situations concerning Chinese aggression with respect to maritime disputes, the need for ongoing military modernization to establish a minimum credible defense remains (Amador 2014). The devastation in the wake of Typhoon Haiyan and the ensuing operation highlighted shortcomings in AFP mobility and logistics needed to respond within Philippine territory, much less in contested maritime space further afield challenged by a more robust potential adversary (Batongbacal 2014). The date also marked the opening of the NCWC, reflecting the US support of US $\$ 20$ million in security assistance to enhance the Philippines ability to monitor its maritime domain. This effort can be seen as a judicious use of assistance from a treaty ally while the modernization process continues (Amador 2014).

In addition to an increase in security assistance from its treaty ally, the US, an idea that some have long advocated for described as "linking spokes" within the US alliance network, the Philippines has also expanded security cooperation with other American allies in Asia (De Castro 2009). A long-time development partner of the Philippines, maritime cooperation with Japan has grown significantly under the Aquino administration. The strategic partnership was established in 2011 with a focus on economic issues, but under Japanese Prime Minister Shinzo Abe's government it has placed greater attention on security matters. The strategic convergence over Chinese assertiveness and threats to freedom of navigation in regional waters has led to more dynamic cooperation. Under the agreement, the Japanese and Philippine Coast Guards conducted their first drill together, training off the coast of Manila Bay to respond to vessels hijacked by pirates (Reuters 2015). Japan agreed to provide the Philippines with official development assistance that would fund 10 patrol boats for the Philippine Coast Guard. The contract was signed in April 2015 and the first delivery of the multi-role response vessels is expected in the third quarter of 2016 (Arthur 2015). Japan is also working with the Philippine Coast Guard to upgrade critical communication systems, addressing a concern over the lack of capability to transmit relevant data for time-sensitive search and rescue operations (Esplanada 2015). The Guidelines for Japan-US Defense Cooperation that were released in April 2015 broadens the scope of their alliance geographically and extends it to third-party countries, which could have important implications for Manila (Hemmings 2015).

Shortly after a mid-term election that made his Liberal Party block an outright majority in the Philippine Senate, President Aquino travelled to Seoul in October 2013 where he signed a memorandum of understanding on defense cooperation with South Korea President Park Geun-Hye. The two leaders discussed the intent of the Philippines to purchase twelve new KA-50 fighter jets from Korean Aerospace Industries (Merced 2014). The agreement for the acquisition was signed in March 2014, despite Beijing's pressure on Seoul to cancel the deal, with the initial deliveries expected in late 2015 and all twelve aircraft by the end of 2017 (Fonbuena 2014a, b). Shortly after the deal was completed, 
the South Koreans donated a decommissioned Pohang-class guided missile corvette to the Philippines, adding needed capability to the patrol contested waters. South Korea is the likely source of the Philippine Navy's plan to purchase two new frigates in a program valued at around US $\$ 410$ million, with three of the four bids for the proposed acquisition coming from South Korean firms (Moss 2014). In 2007 Australia and the Philippines signed a Status of Visiting Forces Agreement (SOVFA) in Canberra and in 2012 the Philippine Senate ratified it (Laude 2014). This enabled the Philippine Navy to take part in Exercise Triton in 2013, the first exercise that brought Philippine Navy personnel to Australia under the SOVFA, training in boarding activities and taking part in the International Fleet Review in Sydney (Depasupil 2013). The Royal Australian Navy has also donated two Landing Craft Heavy ships, former HMAS Tarakan and Brunei that were decommissioned in November 2014 and following refurbishment, are expected to be transferred to the Philippines by the end of the second quarter of 2015 (Fonbuena 2015).

These modernization efforts involving cooperation with the US as well as American allies Australia, Japan, and South Korea are a major component of building that minimum credible defense. They go hand-in-hand with expanded training engagements to boost the capacity of the AFP to effectively employ these upgraded platforms. This was seen during Balikatan 2015 with a dramatic increase in the size of the exercise compared to the previous year, with South Korea and Japan both observing and an Australian contingent taking part in the exercise; the focus of this year's iteration was on the broader maritime domain (Dioquino 2015). The looming 2016 election raises concern, particularly with multi-year procurement plans, as key acquisitions such as anti-submarine warfare helicopters and long-range patrol aircraft have gone through a failed bidding round and needed to be re-bid (Fonbuena 2014a, b). While the Aquino administration has dealt with major domestic setbacks including the revelations related to the Priority Development Assistance Fund or "Pork Barrel" scheme and the tragic Mamasapano raid that took the lives of 44 Philippine National Police Special Action Force operators, it has contributed tremendous resources toward modernizing the security sector towards a minimum credible defense posture.

There is still considerable work to be done. This can be seen in the April 2015 decision to cancel the long-negotiated shore-based missile system acquisition from the Israelis that would have bolstered the territorial defense capability on Palawan and to prioritize limited funding for marksmen rifles, long-range sniper weapon systems, and protective gear for chemical-biological terror threats (De Castro 2015). With the objective of establishing a "Minimum Credible Defense" at a time of growing Chinese presence in contested waters, this appears short-sighted. With the 2016 Election wide open ahead of the October 2015 filing deadline for aspiring candidates for the Philippine Presidency, there is uncertainty looking forward. However, in the words of Vice President Jejomar Binay (2014) from his May 2014 trip to the US, "a stronger American military presence in the Philippines and greater interoperability between our respective armed forces dramatically increases our individual and collective defense capabilities, providing a dramatic deterrent against external aggression." 


\section{Conclusion}

While at times challenging politics thwarts Philippines-US alliance cooperation, a newly invigorated alliance is moving well into its seventh decade. Following the vote that ended the US military presence in the Philippines in 1991, the state of readiness within the AFP drastically declined. Security cooperation resumed in the aftermath of the attacks of September 11 and grew substantially under the Aquino administration. It pursued a defense policy geared towards a negotiated peace in the Southern Philippines and a re-orientation of the AFP towards external defense. The IPSP made the linkage clear between ending internal strife and developing a credible defense posture. While faced with an ever-present external challenge, focused political efforts have yielded progress on peace negotiations. The AFP had to undergo a challenging security sector reform program, while executing an ongoing campaign plan that stressed civil-military relations to support the primacy of the peace process. Ultimately, increased support for military modernization from the Aquino administration, along with that of the US and other American allies in Asia, has laid an important foundation to pursue a more credible defense posture. This effort became much more viable as MILF negotiations moved towards a settlement. Key work remains to be done in the military modernization process and that will require the administration that comes to power in 2016 continue this commitment to building external defense capability. This calls for ongoing alliance cooperation, including the implementation of EDCA, continued collaboration with partners such as South Korea and Japan to realize major acquisition programs and build capacity. Ultimately, the Philippines-US alliance is a vital means to realizing the objective of a "Minimum Credible Defense."

Authors' contributions

AA and JG participated in the conception and design of the study. AA carried out the acquisition of data. AA and JG did the analysis and interpretation of data. Both authors read and approved the final manuscript.

\footnotetext{
Author details

${ }^{1}$ National Institute of Education, Singapore, Singapore. ${ }^{2}$ S. Rajaratnam School of International Studies, Singapore, Singapore.
}

\section{Compliance with ethical guidelines}

Competing interests

The authors declare that they have no competing interests.

Received: 12 August 2015 Accepted: 15 September 2015

Published online: 29 September 2015

\section{References}

Agoncillo, T.A. 1997. Malolos: the crisis of the republic. Quezon City: University of the Philippines Press.

Aguiling-Dalisay, G., J. Yacat, and A. Navarro. 2004. Extending the self: volunteering as pakikipagkapwa. Quezon City: National College of Public Administration and Governance, University of the Philippines.

Agustin, C. 2002. Military exercises in the context of Philippine security requirements. In Paper presented at The Return of Gl Joe: U.S. Troops in Mindanao.

Alagappa, M. (ed.). 2001. Coercion and governance: the declining political role of the military in Asia. Stanford: Stanford University Press.

Amador, J.S. 2014. Eyes on the prize: the Philippines-US alliance and defense modernization. Asia-Pacific Bulletin. http:// www.eastwestcenter.org/publications/eyes-the-prize-the-philippines-us-alliance-and-defense-modernization.

Andres, T., Q. Donato, P. Andres, and C.B. Ilada. 1986. Making Filipino values work for you. Makati: St Paul Publications.

Armed Forces of the Philippines. 2011. Internal peace and security plan. http://www.army.mil.ph/ATR_Website/pdf_files/ IPSP/IPSP\%20Bayanihan.pdf.

Arthur, G. 2012. Joint special operations. Asian Military Review. http://www.asianmilitaryreview.com/ joint-special-operations/. 
Arthur, G. 2015. Contract for Japan-built boast for Philippine Coast Guard awarded. Shephard Media. http://www. shephardmedia.com/news/imps-news/contract-japan-built-boats-philippine-coast-guard-/.

Avila, A.P. 2011. Battling two fronts with one stroke. CTTA: Counterterrorist Trends and Analysis 3(3): 1-3.

Avila, A.P. 2014a. Former rebels take up organic farming in Negros Occidental. Rappler. http://www.rappler.com/ move-ph/issues/57141-reintegrating-former-rebels-through-organic-farming.

Avila, B. 2014b. The U.S. bases, then and tomorrow? The Philippine Star. http://www.philstar.com/ opinion/2014/03/27/1305527/us-bases-then-and-tomorrow.

Bacani, L., Carcamo, D., and Pareno, R. 2013. Zamboanga City shut down as MNLF men attack its villages. Philippine Star. http://www.philstar.com/nation/2013/09/09/1 190051/zamboanga-city-shut-down-mnlf-men-attack-its-villages.

Batino, C. 2013. Philippines' deadliest defense crisis in south under Aquino ends. Bloomberg. http://www.bloomberg. com/news/articles/2013-09-28/philippines-deadliest-defense-crisis-in-south-under-aquino-ends.

Batongbacal, J. 2014. EDCA and the West Philippine Sea. Rappler. http://www.rappler.com/ thought-leaders/77823-edca-west-philippine-sea-america.

Batongbacal, J. 2015. Arbitration 101: Philippines v. China. Asia Maritime Transparency /nitiative. http://amti.csis.org/ arbitration-101-philippines-v-china/.

Bautista, E. 2013. Assumption speech. http://www.afp.mil.ph/index. php/11-others/12-assumption-speech-of-lt-gen-emmanuel-t-bautista.

Bauzon, C.V., and Gutierrez, A.P. 2015. Talks reach dead end. Manila Times. http://www.manilatimes.net/ talks-reach-dead-end/176045/.

BBC News. 2013. Malaysia soldiers attack armed Filipino clan in Borneo. BBC News. http://www.bbc.com/news/ world-asia-21665135.

Binay, J. 2014. The Philippines: facing a rebalancing America and a resurgent China. Speech at the Center for Strategic and International Studies. http://www.ovp.gov.ph/index.php/34-speeches/speeches-on-diplomatic-relations/117speech-of-vice-president-jejomar-c-binay-for-the-csis-sumitro-djojohadikusumo-banyan-tree-leadership-forum-1-may-2014.

Carter, R.L. 2011. Current state of the U.S.-Philippines alliance. U.S. Army War College.

Chalk, P. 2014. Rebuilding while performing: military modernization in the Philippines. Australian Strategic Policy Institute. https://www.aspi.org.au/publications/rebuilding-while-performing-military-modernisation-in-the-philippines.

Comer, K. 2010. Philippine defense reform: Are we there yet? Foreign Military Studies Office. http://fmso.leavenworth.army. mil/documents/Philippine_Defense_Reform.pdf.

Daggett, S., Dolven, B., Lawrence, S.V., Manyin, M.E., Martin, M.F., O'Rourke, R., and Vaughn, B. 2012. Pivot to the Pacific? The Obama administration's "rebalancing" toward Asia: Congressional Research Service.

Davide Fact-Finding Commission. 1990. The final report of the fact-finding commission. Makati Bookmark.

De Castro, R. 2007. China, the Philippines, and U.S. influence in Asia. American Enterprise Institute. http://www.aei.org/ publication/china-the-philippines-and-u-s-influence-in-asia/.

De Castro, R. 2009. Exploring a 21st century Japan-Philippine security relationship. Asian Security 49(4): 691-715.

De Castro, R. 2015. Is the Philippines military modernization dead in the water? The Diplomat. http://thediplomat. com/2015/07/is-the-philippines-military-modernization-dead-in-the-water/.

De Castro, R., and Lohman, W. 2012. Getting the Philippines Air Force flying again: the role of the U.S.Philippines alliance. Heritage Foundation. http://www.heritage.org/research/reports/2012/09/ getting-the-philippines-air-force-flying-again-the-role-of-the-us-philippines-alliance.

De La Cruz, A. 2013. Heirs of Sultan of Sulu pursue Sabah claim on their own. Philippine Daily Inquirer. http://globalnation. inquirer.net/64577/heirs-of-sultan-of-sulu-pursue-sabah-claim-on-their-own/.

Department of National Defense. 2015. Former secretaries. http://www.dnd.gov.ph/transparency/former-secretaries. html.

Depasupil, W.B. 2013. PN joins Australia's exercise triton. Manila Times. http://www.manilatimes.net/ pn-joins-australias-exercise-triton/42069/.

Dioquino, R.-A.J. 2015. Balikatan 2015 to focus on maritime security not West PHL Sea issue, say officials. GMA News. http://www.gmanetwork.com/news/story/472874/news/nation/ balikatan-2015-to-focus-on-maritime-security-not-on-west-phl-sea-issue-say-officials.

Dizon, N., and Ubac, M.L. 2013. Bautista a new AFP chief. Philippine Daily Inquirer. http://newsinfo.inquirer.net/340973/ bautista-named-next-afp-chief.

Dyer, G. 2014. U.S. strategists face dilemma over Beijing claim in South China Sea. Financial Times. http://www.ft.com/ cms/s/0/b2176dea-0732-11 e4-81c6-00144feab7de.html\#axzz3XFvHKxBg.

Emerson, D. 2012. ASEAN Stumbles in Phnom Penh. East Asia Forum. http://www.eastasiaforum.org/2012/07/23/ asean-stumbles-in-phnom-penh-2/.

Esplanada, J.E. 2015. Palace oks more ships, planes for Coast Guard. Philippine Daily Inquirer. http://newsinfo.inquirer. net/685288/palace-oks-more-ships-planes-for-coast-guard.

Fernandez, A. 2012. Roadmap for peace: highlights of the Bangsamoro Framework Agreement. GMA News. http://www.gmanetwork.com/news/story/278325/news/nation/ road-map-for-peace-highlights-of-the-bangsamoro-framework-agreement.

Ferrer, R.B., and C. Hernandez. 2013. The military in democratic development: a Philippine case study. In Military engagement: influencing armed forces worldwide to support democratic transitions, vol. 2, ed. D.C. Blair, 139-164. Washington DC: Brookings Institution Press.

Fonbuena, C. 2014a. PH Air Force a joke no more, gets fighter jets. Rappler. http://www.rappler.com/ nation/54125-philippine-air-force-fighter-jets.

Fonbuena, C. 2014b. PH rebids anti-submarine choppers. Rappler. http://www.rappler.com/ nation/70582-philippines-anti-submarine-choppers.

Fonbuena, C. 2015. Australia's gift to PH Navy: 2 supply ships. Rappler. http://www.rappler.com/ nation/82331-australia-gift-philippine-navy-ships.

Franco, J. 2013. Malaysia: Unsung hero of the Philippine peace process. Asian Security 9(3): 211-230. 
Garamone, J. 2003. Philippines to become major Non-NATO Ally, Bush says. Armed Forces Press Service. http://www. defense.gov/news/newsarticle.aspx?id=28968.

Gazmin, V., and Goldberg, P. 2014. Enchanced defense cooperation agreement. http://www.gov.ph/2014/04/29/ document-enhanced-defense-cooperation-agreement/.

GMA News. 2013. MNLF confirms 'declaration of independence', girds itself for possible fighting. GMA News. http://www.gmanetwork.com/news/story/322239/news/regions/ mnlf-confirms-declaration-of-independence-girds-itself-for-possible-fighting.

Goldberg, S.D. 1976. The bases of civilian control of the military in the Philippines. In Civilian control of the military: theory and cases from developing countries, ed. C.E.J. Welch. New York: State University of New York Press.

Goldman, J. 2014. Resilience in the Philippines in the face of natural calamities. Diplomatic Courier. http://diplomaticourier.com/news/regions/asia/2199-resilience-in-the-philippines-in-the-face-of-natural-calamities.

Hemmings, J. 2015. Japan chair platform: how will the new U.S.-Japan defense guidelines affect regional security? Center for Strategic \& International Studies. http://csis.org/publication/ japan-chair-platform-how-will-new-us-japan-defense-guidelines-affect-regional-security.

Hernandez, C. (1979). The extent of civilian control of the military in the Philippines 1946-1976. Ph.D., University of New York, Buffalo.

Human Development Network. 2005. Philippine human development report: peace, human security and human development in the Philippines. Manila: Human Development Network.

Institute for Strategic Studies and Development Studies. 2011. Developing a security sector reform index in the Philippines: towards conflict prevention and peace-building (pre-publication version). Quezon City: Institute for Strategic and Development Studies.

Integrated Regional Information Networks. 2010. Philippines: Aquino pledges renewed peace efforts. Integrated Regional Information Networks. http://www.irinnews.org/report/89676/philippines-aquino-pledges-renewed-peace-efforts.

Jacobs, A. 2013. Typhoon response highlights weaknesses in Philippine Military. The New York Times. http://www.nytimes. com/2013/11/20/world/asia/typhoon-response-highlights-weaknesses-in-philippine-military.html.

Koh, C. 2013. Typhoon Haiyan and ASEAN's naval effort. The Diplomat. http://thediplomat.com/2013/12/ typhoon-haiyan-and-aseans-naval-effort/.

Lapena, C.G. 2012. Stakeholder's involvement necessary for success in AFP's security plan. GMA News. http://www.gmanetwork.com/news/story/260123/news/nation/ stakeholders-involvement-necessary-for-success-in-afp-s-security-plan-army-chief.

Laude, J. 2008. Pentagon commits firm support to AFP coast watch in south. Philippine Star. http://www.philstar.com/ headlines/72094/pentagon-commits-firm-support-afp-coast-watch-south.

Laude, J. 2014. Phl, Australia hold naval games. Philippine Star. http://www.philstar.com/nation/2014/10/09/1377954/ phl-australia-hold-naval-games.

Lee-Brago, P. 2015. Maritime monitoring seen to improve with coast watch centr. Philippine Star. http://www.philstar. com/headlines/2015/05/02/1450290/maritime-monitoring-seen-improve-coast-watch-center.

Leoncini, D.L.P. 2005. A conceptual analysis of Pakikisama. In Filipino cultural straits, ed. Gripaldo, R.M. (Vol. 4, pp. 157-184). Washington DC: The Council for Research in Values and Philosophy.

Lopez, R.B. 2014. Balikatan 2014 happens this month. Manila Bulletin. http://www.mb.com.ph/ balikatan-2014-starts-today/.

Lubold, G. 2015. Pentagon says China has stepped up land reclamation in the South China Sea. The Wall Street Journal. http://www.wsj.com/articles/ pentagon-says-china-has-stepped-up-land-reclamation-in-south-china-sea-1440120837.

Lum, T., and Dolven, B. 2014. The Republic of the Philippines and U.S. interests. Congressional Research Service. https://fas. $\mathrm{org} / \mathrm{sgp} / \mathrm{crs} / \mathrm{row} / \mathrm{R} 43498 . \mathrm{pdf}$.

Lum, T., and Margesson, R. 2014. Typhoon Haiyan (Yolanda): U.S. and international response to Philippines disaster. Congressional Research Service. https://www.fas.org/sgp/crs/row/R43309.pdf.

Marasigan, C.S. 2013. Firm bags contract to boost border patrol. Businessworld. http://www.bworldonline.com/content. php?section=Nation\&title=Firm-bags-contract-to-boost-border-patrol\&id $=75480$.

Maxwell, D.S. 2004. Operation enduring freedom-Philippines: what would Sun Tzu say. Military Review 84(3): 20.

Maxwell, D.S. 2013. Partnership, respect guide U.S. military role in the Philippines. World Politics Review. http://www.worldpoliticsreview.com/articles/12685/partnership-respect-guide-u-s-military-role-in-philippines.

McGeown, K. 2011. Philippines Muslim rebels in talks in Malaysia. http://www.bbc.com/news/ world-asia-pacific-12402821.

Merced, L.D.C. 2014. The potentials and limits of Philippines-South Korea maritime defense cooperation. FSI Insights. http://www.fsi.gov.ph/wp-content/uploads/2014/09/2014-08-Vol-1-No-4-September-FSI-Insights-Merced.pdf.

Milman, O. 2015. Life in the Philippines: preparing the next typhoon Haiyan. The Guardian. http://www.theguardian.com/ environment/2015/mar/25/life-in-the-philippines-preparing-for-the-next-typhoon-haiyan.

Miranda, F. B. 1992. The politicization of the military. Quezon City: Center for Integrative and Development Studies, University of the Philippines.

Moss, T. 2014. South Korea gifts a warship to the Philippines. Wall Street Journal. http://blogs.wsj.com/ indonesiarealtime/2014/06/08/south-korea-gifts-a-warship-to-the-philippines/.

Munson, M. 2013. The siege in Zamboanga City. Center for International Maritime Security. http://cimsec.org/ latest-stand-zamboanga-city/7457.

Office of the President. 2011. Establishment of the National Coast Watch System. (Executive Order 57). Malacang Palace.

Panda, A. 2014. US, Philippines begin annual 'Balikatan' military exercise. The Diplomat. http://thediplomat.com/2014/05/ us-philippines-begin-annual-balikatan-military-exercise/.

Perlez, J. 2012. China and Philippines ease standoff in South China Sea. New York Times. http://www.nytimes. com/2012/06/19/world/asia/beijing-and-manila-ease-tensions-in-south-china-sea.html.

Philippine Star. 2012. Aquino signs revised AFP modernization act. Philippine Star. http://www.philstar.com/ headlines/2012/12/11/884844/aquino-signs-revised-afp-modernization-act. 
Porcalla, D. 2011. Aquino forms National Coast Watch System. Philippine Star. http://www.philstar.com/headlines/725918/ aquino-forms-national-coast-watch-system.

Rahmat, R. 2015. PT PAL Outlines weapons fit for Philippine Navy SSVs. HIS Jane's 360. http://www.janes.com/ article/53644/pt-pal-outlines-weapons-fit-for-philippine-navy-ssvs.

Ratner, E. 2013. Learning the lessons of Scarborough Reef. The National Interest. http://nationalinterest.org/commentary/ learning-the-lessons-scarborough-reef-9442.

Reuters. 2015. Philippines, Japan coast guards hold anti-piracy drills. Reuters. http://in.reuters.com/article/2015/05/06/ philippines-japan-idINKBNONR0OD20150506.

Rood, S. 2010. Next Philippine President Noynoy pledges peace, but how? The Asia Foundation. http://asiafoundation. org/in-asia/2010/06/25/next-philippine-president-noynoy-aquino-pledges-peace-but-how/.

Rosen, S.P. 2015. How America can balance China's rising power in Asia. The Wall Street Journal. http://www.wsj.com/ articles/how-america-can-balance-chinas-rising-power-in-asia-1433199409.

Ryan, J. 2011. Senate condemns China for South China Sea actions. The Hill. http://thehill.com/blogs/floor-action/ senate/168693-senate-condemns-china-for-south-sea-actions.

Shenon, P. 1992. Philippine Senate votes to reject U.S. base renewal. The New York Times. http://www.nytimes. com/1991/09/16/world/philippine-senate-votes-to-reject-us-base-renewal.html.

Sothanarith, K. 2015. Cambodia publicly endorses China position on South China Sea. Voice of America. http://www. voanews.com/content/cambodia-publicly-endorses-china-position-on-south-china-sea/2694301.html.

The Feliciano Fact-Finding Commission. 2003. The report of the fact-finding commission. Manila: Office of the President.

The Economist. 2011. Carps among the Spratlys. http://www.economist.com/node/18332702.

Tonson, M.A.R. 2011. PHL's biggest warship vs. China's first aircraft carrier. GMA News. http://www.gmanetwork.com/ news/story/228531/scitech/phl-s-biggest-warship-vs-china-s-first-aircraft-carrier.

U.S. Department of State. 2011. Signing of the Manila declaration on board USS Fitzgerald in Manila Bay. Manila.

Yabes, C. 2008. Defense reform should be in place by 2011. Newsbreak. http://www.abs-cbnnews.com/ nation/09/11/08/\%E2\%80\%98defense-reform-should-be-place-2011\%E2\%80\%99.

\section{Submit your manuscript to a SpringerOpen ${ }^{\circ}$ journal and benefit from:}

- Convenient online submission

- Rigorous peer review

- Immediate publication on acceptance

- Open access: articles freely available online

- High visibility within the field

- Retaining the copyright to your article

Submit your next manuscript at $\mathbf{s p r i n g e r o p e n . c o m ~}$ 